УДК 021.6(477)

DOI: 10.31866/2616-7654.8.2021.247585

\section{ФУНКЦІОНАЛЬНИЙ ПОТЕНЦІАЛ ДІЯЛЬНОСТІ ВГО УКРАЇНСЬКА БІБЛІОТЕЧНА АСОЦІАЦІЯ 3 РОЗВИТКУ БІБЛІОТЕЧНОЇ СПРАВИ}

Альона Мотько, аспірантка кафедри інформаційних технологій Київського національного університету культури і мистецтв (Україна, Киів) e-mail: alyona94@meta.ua ORCID: 0000-0002-5513-882X

Стаття присвячена розкриттю функціонального потенціалу ВГО Українська бібліотечна асоціація (УБА) як відкритої професійної організації, яка спрямовує свої зусилля на розвиток бібліотечної справи в Україні і зміцнення в державі демократичних засад суспільного розвитку.

Використання комплексу дослідницьких методів, основними з яких було визначено соціальнокомунікаційний, системний та функціональний методи, а також емпіричні методи включеного і зовнішнього спостереження, зумовило розгляд УБА та їі діяльності 3 позицій виконання організацією взятих на себе зобов’язань, її відповідності очікуванням бібліотечного співтовариства. Реалізацію окремих функцій УБА та напрямів її діяльності розкрито як систему взаємопов'язаних форм та інструментів, які взаємодоповнюють один одного, посилюючи підсумковий ефект.

Створення УБА розглянуто як відповідь професійної спільноти на потребу вирішення певних завдань та реалізації ряду функцій як стосовно розвитку вітчизняної бібліотечної справи, так і суспільства в цілому. Уперше обгрунтовано функціонування УБА як відкритої адаптивної лідерської організації, що реалізує організаційну, мобілізаційно-мотивуючу, комунікаційно-координаційну, інформаційну, освітню, науково-методичну, консолідуючу, представницьку, адвокаційну, компенсаторну функції. Розкрито змістовне наповнення окремих функцій.

Призначенням компенсаторної функції визначено забезпечення бібліотекам необхідного теоретичного та практичного підгрунтя для ефективної реалізації перспективних напрямів діяльності в умовах відсутності відповідних ухвалених керівних документів загальнодержавного рівня. Виявлено, що від початку створення УБА її статутними документами не передбачалось здійснення компенсаторної функції, проте під час розгортання діяльності асоціації і увиразнення її орієнтованості на оперативне й ефективне вирішення актуальних завдань у розвитку бібліотечної справи, іï реалізація стала важливим напрямом функціонування організації.

Ключові слова: ВГО Українська бібліотечна асоціація, УБА, функції УБА, бібліотека, бібліотечна справа, компенсаторна функція. 
Український журнал з бібліотекознавства та інформаційних наук. Випуск 8 (2021) Ukrainian Journal on Library and Information Science. Issue 8 (2021)

\section{ВСТУП}

Бібліотеки визначаються як ключовий елемент культурної, наукової, освітньої, інформаційної інфраструктури держави ("Про схвалення Стратегії", 2016). Ефективність функціонування бібліотек сприяє розвитку економічного і людського потенціалу суспільства.

Потужною професійною платформою, що здійснює суттєвий вплив на розвиток бібліотечної професії та управління галуззю, сприяє модернізації бібліотечної справи в Україні, є ВГО Українська бібліотечна асоціація (далі - УБА). При цьому УБА активізує свою діяльність не лише в напрямі підтримки бібліотечної справи, але й у формуванні суспільної думки стосовно актуальних питань державного і суспільного розвитку - підвищення рівня правової культури, реформи децентралізації, медичної реформи тощо. Комплексному осмисленню внеску УБА в розбудову бібліотечної справи в Україні і зміцнення демократичних засад суспільного розвитку сприятиме розкриття її функціонального потенціалу.

Метою дослідження є обгрунтування функціонального потенціалу УБА, розкриття змісту окремих функцій, що реалізуються асоціацією під час її діяльності.

\section{ТЕОРЕТИЧНЕ ПІДГРУНТЯ}

На сьогодні грунтовного наукового осмислення досвіду функціонування УБА, організаційних і функціональних засад діяльності асоціації щодо розвитку бібліотечної справи в Україні поки що не відбулося, комплексні наукові праці дисертаційного рівня, присвячені УБА, в бібліотекознавстві відсутні.

Як засвідчив аналіз захищених дисертацій за фаховим спрямуванням, еволюція і функціонування УБА не стали на разі предметом спеціального наукового узагальнення. Лише частково діяльність організації на етапі становлення була висвітлена В. С. Пашковою (2010а) в контексті розгляду еволюції національних бібліотечних асоціацій (1876-2009 рр.), Ю. В. Трач (2001) у аспекті професійного розвитку бібліотечного фахівця, А. М. Плахтій (2021) у рамках участі бібліотек у реалізації електронного урядування, О. О. Шендрик (2018) у вимірі міжнародної діяльності бібліотек.

Вивчення фахової наукової літератури дало змогу з'ясувати, що різні аспекти діяльності УБА згадуються в ряді окремих публікаціях вітчизняних науковців, серед яких В. Бабич (Бабич \& Сошинська, 1995), О. Воскобойнікова-Гузєва (2018), Т. Добко і В. Загуменна (Добко, 2003; Добко \& Загуменна, 1996, Загуменна, 1997), Л. Ковальчук (2010), В. Пашкова (2005, 2007, 2010 b), Я. Сошинська й І. Шевченко (2012) та ін.

Віддаючи належне грунтовним напрацюванням згаданих науковців, варто, утім, констатувати, що комплексного розкриття функціонального потенціалу ВГО Українська бібліотечна асоціація у діяльності з розвитку бібліотечної справи в Україні в їхніх працях не відбулося.

\section{МЕТОДИ І МАТЕРІАЛИ}

Основними для дослідження було визначено соціальнокомунікаційний, системний та функціональний методи, а також емпіричні методи включеного і зовнішнього спостереження через членство автора у ВГО Українська бібліотечна асоціація. 
Використання соціальнокомунікаційного методу зумовило розгляд УБА та її діяльності з позицій виконання організацією взятих на себе зобов'язань, її відповідності очікуванням бібліотечної спільноти як координаційного центру бібліотек з урахуванням їх різних видів, виходячи з розуміння бібліотеки як соціального інституту.

При цьому застосування соціальнокомунікаційного методу потребувало визначення і обгрунтування функціонального потенціалу УБА, осмислення якого уможливлює комплексне розуміння місця і ролі асоціації в системі соціальних професійних зв'язків і розвитку бібліотечної справи, а також виявлення і опис тих напрямів, інструментів, форм роботи УБА, які забезпечують реалізацію організацією своїх соціальних функцій.

Системний підхід був застосований для вивчення окремих функцій УБА і напрямів її діяльності, даючи змогу розглядати їх як систему форм та інструментів, які взаємодоповнюють один одного, посилюючи підсумковий ефект. Так, обгрунтування реалізації УБА інформаційної функції із застосуванням системного підходу дало змогу розглядати функціонування таких окремих інформаційних інструментів, що використовуються УБА, як офіційний веб-портал, бюлетень УБА «БібліоТека», офіційні представництва в соціальних мережах, статті у фахових журналах та профільних виданнях, професійні форуми, в рамках єдиної інформаційної політики організації з позицій синергетичного ефекту. Своєю чергою реалізація освітнього напряму УБА розкривалась як система дій наукового, науково-методичного та практичного спрямування, які доповнюють і посилюють один одного.

\section{РЕЗУЛЬТАТИ ДОСЛІДЖЕННЯ}

ВГО Українська бібліотечна асоціація від початку своєї діяльності і до сьогодні $\epsilon$ елементом структури громадянського суспільства, організацією, створення якої було обумовлено потребою вирішення певних завдань та реалізації ряду функцій як стосовно розвитку вітчизняної бібліотечної справи, так і суспільства в цілому, серед яких: організаційно-консолідуюча, мобілізаційно-мотивуюча, комунікаційно-координаційна, інформаційна, освітня, науково-методична, представницька та адвокаційна. Розглянемо прояв цих функцій більш детально.

Організаційно-консолідуюча функція.

Проявом реалізації організаційно-консолідуючої функції стало, власне, створення самої організації, яка об'єднала на той момент тих суб'єктів бібліотечно-інформаційної діяльності, які після розпаду Радянського Союзу прагнули осучаснити вітчизняні бібліотечні установи, модернізувати бібліотечну справу в цілому, проте не могли цього зробити поодинці. Українська бібліотечна асоціація позиціонує себе як відкриту громадську організацію, яка об’єднує на добровільних засадах професійно пов’язаних осіб. Це гуртування активної громади у бібліотечному колі. Відповідно, УБА стала організацією, яка об’єднала вмотивованих до змін бібліотекарів, організувала їх діяльність і в такий спосіб заклала підвалини для створення умов для налагодження функціонування оновленої бібліотечної системи.

Також, слід відзначити, що на початку діяльності УБА було організовано їі структуру, до якої входили: президія (29 осіб), регіональні відділення (близько 26 регіонів), формувалися секції (11) та створювались філії, які допомагали ор- 
ганізуватися бібліотекарям на місцях, згідно з розробленими документами УБА. При цьому було створено умови «для кожного члена організації брати участь в удосконаленні інформаційно-бібліотечної політики, у розробленні відповідної законодавчої бази, а також впливати на їхню реалізацію» (Пашкова, 2010а, с. 2).

Мобілізаційно-мотивуюча функція.

Мобілізаційно-мотивуюча функція передбачає залучення бібліотекарів до певних проєктів, подій, ініціатив. Тобто ідеться про формування активної позиції, адже мотивація визначається як «спонукання до дії; динамічний процес фізіологічного та психологічного плану, керуючий поведінкою людини, який визначає її організованість, активність і стійкість; здатність людини діяльно задовольняти свої потреби» ("Мотивація", 2021). В управлінні мотивація - це «процес стимулювання працівників до здійснення ефективної діяльності, спрямованої на досягнення цілей підприємства» ("Мотивація", 2021).

Мобілізаційно-мотивуюча функція УБА як на початку її діяльності, так і сьогодні є надзвичайно важливою, адже мотивація і мобілізація зусиль необхідні для ухвалення певних рішень, а згодом - для їх виконання та реалізації завдань. Слід додати, що така позиція є принциповою характеристикою для демократичної держави з розвиненим громадянським суспільством. Адже саме здатність до активної поведінки, готовність до спільного вирішення суспільних і професійних завдань є проявами таких якостей, як свобода і відповідальність - одних із головних цінностей демократичної держави. Ці якості притаманні громадянському суспільству, яке, на відміну від просто публіки з пасивним спогляданням та очікуванням, виявляє активну позицію як стосовно суспільного, так і державного розвитку і функціонує як впливовий суб'єкт суспільних відносин. Як засвідчив досвід вітчизняних бібліотек, пасивне очікування оперативних та ефективних рішень від держави в умовах кризи створюєризик занепаду, більш результативною $€$ здатність до об'єднання і координації зусиль, що потребує вмотивованості до дії і вміння мобілізувати наявний потенціал.

Статутом УБА з мотиваційною метою передбачено можливість встановлення форм морального стимулювання: присудження відзнак, вручення грамот членам, проведення конкурсів із питань бібліотечно-інформаційної діяльності. Відповідно до документу, УБА також може ініціювати і сприяти проведенню мітингів, громадських акцій (у тому числі акцій протесту) та інших заходів, а також «ідейно, організаційно підтримує своїх членів, інші об'єднання громадян, надає допомогу в їх створенні» (Статут громадської організації, 2018).

Здатність до реалізації мобілізаційно-мотивуючої функції - це певний виклик для УБА, оскільки свідомість багатьох людей i, зокрема, професійних бібліотекарів, залишається багато в чому ще радянською. І навіть сьогодні у професійному середовищі бібліотекарів можна спостерігати вичікувальну позицію, коли люди просто чекають певних розпоряджень від керівництва, не ризикуючи проявляти власну ініціативу. При цьому відсутність сформованої маркетингової культури, в рамках якої наявне розуміння корпоративного партнерства і важливості діалогу між керівником і підлеглим, стає додатковою проблемою, що ускладнює виявлення активної професійної поведінки, знижує здатність генерувати нові ідеї і бажання щось змінювати. 
Відповідно, в другій половині 90-х років XX ст., невдовзі після розпаду СРСР і утворення незалежної України, реалізація мобілізаційно-мотиваційної функції УБА була складним завданням. Адже на той час ішлося про відсутність напрацьованих практик, позитивних результатів, обгрунтованих перспектив. Члени УБА своїм прикладом показували, що зміни можливі, що УБА варта довіри, адже це були успішні люди, які проявили себе лідерами у професії і суспільстві.

Про успішність реалізації УБА мобілізаційно-мотиваційної функції свідчить проведення асоціацією різних креативних заходів, конкурсів, відзнак, акцій, флешмобів тощо від початку своєї діяльності. Аналіз бюлетенів УБА за період із 2010 по 2021 роки доводить, що УБА активно долучається до різноманітних заходів або організовує їх сама.

Зокрема, проведення УБА та її членами флешмобів спонукає бібліотечних фахівців до кооперації та згуртованості, до просування українських книгозбірень та бібліотечної професії загалом. Наприклад, у 2010 році під час 17-ї Міжнародної Конференції «Крим 2010» за ініціативи членів УБА на відкритті Конференції було проведено танцювальний флешмоб «Користуйся каталогом і не забувай про бази даних», який згуртував українську делегацію та інших членів (Сошинська, 2010 , с. 3). Також ілюстративними є флешмоби, які популяризують книгу, бібліотеку, читання: \#читайукраїнське (2017р.), який розпочато Українським інститутом книги у соціальних мережах та медіа; міжнародний флешмоб «Великий Шевченко» (2019 р.) до 205-річчя від дня народження Великого Кобзаря, у рамках якого треба було зняти відео біля пам'ятника Т. Г. Шевченку, читаючи його вірші, опублікувати відео на власній сторінці у Facebook iз хештегом \#ByShevchenko, зазначити місто та людей, яким передається флешмоб; радіофлешмоб «Good Silent Party» (2016 р.); «Більше поезії у бібліотеках» (2017р.) та ін.

Помітними подіями стало проведення акцій «Бібліотека чекає на тебе!», «Читай! Формат не має значення», «Я люблю свою бібліотеку» та ін. (2011р.); акції велосипедного туру книгозбірнями Рівного «Крути педалі уперед» (2013); масштабної акції у Києві на Хрещатику під час святкування Всеукраїнського дня бібліотек УБА, покликаної привернути увагу громадськості до бібліотек та популяризувати нові бібліотечні послуги у 2012 р. та ін.

Крім цього, різноманітні акції влаштовуються УБА в рамках окремих форумів. Так, під час Львівського бібліотечного форуму члени асоціації організовують вуличні читання у центрі Львова.

Яскраві заходи від УБА ламають стереотипи стосовно бібліотек як несучасних установ зі стосами запилених книжок і бібліотекарями з позаминулого століття, які втратили зв’язок із реальністю і сучасним користувачем, i спрямовані на покращення іміджу бібліотечних працівників. Промовистим у цьому контексті став флешмоб 2020 р. львівських бібліотекарок на чолі із членкинею президії УБА, директоркою Львівської обласної бібліотеки для дітей Л. Луговою та директоркою Львівської міської бібліотеки для дорослих імені Романа Іваничука Т. Пилипець, під час якого бібліотекарки протанцювали вулицями міста «бібліотечний рок-н-рол» під однойменну пісню у виконанні головної редакторки Видавництва Старого Лева, поетеси, вокалістки і співзасновниці тріо «Мар'яничі» Мар'яни Савки. За словами останньої, «бібліотекарки - дуже драйвові і креативні. Що у відео «Бібліотечний 
Український журнал з бібліотекознавства та інформаційних наук. Випуск 8 (2021) Ukrainian Journal on Library and Information Science. Issue 8 (2021)

рок-н-рол» й можна побачити: у цих жінок - прекрасне почуття гумору, багато внутрішньої свободи і невичерпний оптимізм» ("До Всеукраїнського дня", 2020).

Мотиваційні конкурси й акції влаштовуються як на загальноукраїнському, так і на регіональному рівнях.

Наприклад, у 2017 р. Луганське обласне відділення УБА оголосило конкурс серед молодих бібліотекарів області «Бібліотекар NEXT: нульовий відлік», який передбачав розробку молодими бібліотекарями креативної громадської ініціативи спільно з молоддю населених пунктів, де безпосередньо працюють бібліотекарі. Своєю чергою, Рівненське обласне відділення УБА у 2011 р. ініціювало проведення обласного фестивалю-конкурсу інноваційного бібліотечного досвіду «БібліоЧлени»; у 2020 році проведено Всеукраїнський конкурс «Творчий злет: молодий бібліотекар року 2020» та ін.

Також, для мотивації та спонукання до вдосконалення, поширення кращого досвіду УБА було впроваджено низку почесних відзнак, як-от «За відданість бібліотечній справі», «За внесок у бібліотекознавство», «За внесок у бібліотечну освіту», «Краще регіональне відділення», а також започатковано низку конкурсів, серед яких Всеукраїнський конкурс «Творчий злет: молодий бібліотекар року», Всеукраїнський конкурс «Бібліотека року», конкурси інтернет-сайтів, електронних каталогів, відеоробіт, наукових робіт та ін.

Комунікаційно-координаційна функція.

ВГО Українська бібліотечна асоціація - це середовище професійної комунікації. Про це, зокрема, зазначається у Статуті організації (Статут громадської організації, 2018), яка сприяє налагодженню сталого, постійного, стабільного зв’язку між різними членами асоціації, між керівними органами УБА і її місцевими осередками, всередині керівництва асоціації.

Комунікація всередині асоціації здійснюється як опосередковано (наприклад, через електронну пошту, веб-сайт або інформаційний бюлетень, електронні опитування та реєстраційні форми, створені в Google-документах), так і безпосередньо під час науково-практичних та звітно-виборних конференцій, засідань президії УБА, проведення науково-освітніх заходів, флешмобів, акцій тощо, які виконують роль професійних комунікаційних майданчиків. При цьому організація таких заходів потребує ефективної координації зусиль і дій різних учасників у межах усієї країни.

У зв’язку з цим, передусім, заслуговує на увагу реалізація УБА проєктів, які охоплюють як різні бібліотечні установи країни, так і залучають партнерів поза бібліотечними інституціями. Наприклад, реалізація проєкту «Чотири простори бібліотеки: інноваційна модель діяльності» (2020р.) передбачала координацію безпосередньо колективів бібліотек, які модернізували свої простори, авторів посібника, який містив рекомендації щодо практичної організації роботи публічної бібліотеки в нових умовах і пропонував дизайнерські рішення оформлення бібліотечних просторів, учасників онлайн-форуму для міні-команд об'єднаних територіальних команд, відібраних на конкурсній основі, та експертів, які надавали консультації щодо створення кожного з чотирьох бібліотечних просторів.

Також слід згадати такі щорічні конференції УБА, як Міжнародна конференція «Сучасна бібліотечно-інформаційна безперервна освіта», Львівський міжнародний бібліотечний форум, щорічна конференція Української бібліотечної асоціації 
тощо; молодіжні заходи, зокрема, «Міжнародний форум молодих бібліотекарів УБА»; «Літня та зимові школи молодих бібліотекарів УБА»; «Онлайнове мережування молодих бібліотекарів Української бібліотечної асоціації» та ін.

Ілюстративним у цьому контексті є приклад Львівського міжнародного бібліотечного форуму, започаткованого у 2010 р. ГО «Форум видавців» та Українською бібліотечною асоціацією, який став «місцем зустрічі керівників і провідних фахівців бібліотек, науковців, викладачів закладів вищої освіти, видавців, авторів, читачів, провайдерів інформаційних послуг, членів та партнерів Української бібліотечної асоціації» ("У Львові відбудеться", 2019).

Участь у форумі в різні роки брали генеральний директор Директорату внутрішньої та гуманітарної політики Офісу Президента України Вероніка Селега (2020 р.), заступник міністра культури та інформаційної політики Лариса Петасюк (2020р.), директорка ГО «Форум видавців» Катерина Шевченко (2020р.), канд. філос. наук, директор Центру Європейських гуманітарних досліджень Національного університету «Києво-Могилянська академія» та науково-видавничого об’єднання «Дух і Літера» Костянтин Сігов (2020р.), письменник і громадський діяч Сергій Жадан (2019 р.), голова «Unichek Україна» Андрій Сідляренко (2019 p.), координатор проекту IREX Тетяна Таренкова (2019 р.), заступник міністра культури України Юрій Рибачук (2017р.), директор Українського інституту книги Тетяна Терен (2017р.), директор Центру ім. Митрополита Андрея Шептицького Українського католицького університету Олег Яськів (2017р.) та ін.; такі зарубіжні фахівці, як Барбара Лізон, президентка-елект (2019-2021рр.) Міжнародної федерації бібліотечних асоціацій та установ (IFLA), Беттіна Венцель, керівниця відділу «Інформація та бібліотека» Goethe-Institut в Україні, Уте Енгелкенмайєр, очільниця Департаменту сервісу та інформації Бібліотеки Дортмундського технічного університету, Софі Маннс-Зюсбріх, членкиня комісії з питань професійної кваліфікації Німецької бібліотечної асоціації, Петрас Зурліс, директор Вільнюської обласної публічної бібліотеки ім. Адама Міцкевича, Пола Кауфман, пані декан бібліотек, директорка бібліотеки Іллінойського університету м. Урбан-Шампейн та ін. 2020 р. до участі у Львівському міжнародному бібліотечному форумі, який проходив у онлайн-форматі, було залучено 250 осіб - фахівців бібліотек різних видів і з різних регіонів України та з-за кордону. Учасниками форуму 2019 р. стали близько 300 осіб. 2016 р. «у роботі Львівського бібліотечного форуму взяли участь понад 100 фахівців інформаційної, бібліотечної, архівної, музейної і видавничої справи, представники вищих навчальних закладів, органів державного управління та громадських організацій з України, Польщі, Литви, Білорусі. Форум працював чотири дні на понад десяти площадках бібліотек та університетів м. Львів» (Падалка, 2016).

Прикладом ефективної координації в межах країни стала підтримка УБА ініціативи, розпочатої 2016 р. молодіжною групою Луганської обласної бібліотеки імені О. М. Горького, «Тиха вечірка в бібліотеці», під час якої бібліотеки з різних куточків України мали змогу онлайн долучитися до акції. Розпочали «вечірку» Луганська та Ужгородська ОУНБ. Кожен учасник флешмобу, перебуваючи у приміщенні бібліотеки, «міг приєднатися до радіоефіру, вдягнувши навушники та слухаючи музику, що транслюватиметься на базі онлайн-радіо «Сковорода» ("Запрошуємо бібліотеки України", 2016). Таким чином упродовж флешмобу будь-яка 
Український журнал з бібліотекознавства та інформаційних наук. Випуск 8 (2021) Ukrainian Journal on Library and Information Science. Issue 8 (2021)

бібліотека, незалежно від місця її розташування, мала змогу приєднатися до заходу та провести «тиху вечірку» у своєму бібліотечному приміщенні, слідуючи загальному сценарію.

Кращій координації і злагодженості діяльності різних осередків і структур УБА сприяє щорічне визначення девізу УБА, під гаслом якого проходять заходи протягом року. Вперше конкурс девізів був організований президією УБА до Всеукраїнського дня бібліотек у 2009 р. Упродовж 2009-2021 рр. переможцями конкурсу обирались такі гасла: «Бібліотек@ - твоє вікно у світ» (2009), «Бібліотек@ - світ нових можливостей» (2010), «Бібліотек@: інформація - знання - успіх» (2011), «Бібліотек@: створи своє майбутнє» (2012), «Бібліотек@: територія ідей» (2013), «Бібліотек@ - територія єдності» (2014), «Бібліотек@ - діалог, культура, мир!» (2015), «Бібліотек@: сучасна, креативна, твоя!» (2016), «Бібліотек@: знай, мрій, твори!» (2017), «Бібліотек@ - все тут, всі тут!» (2018), «Бібліотека: час змін - час дій!» (2019), «Бібліотека - Всесвіт у зручному форматі» (2020), «Бібліотека - твоя точка опори» (2021) (Українська бібліотечна асоціація. PR-матеріали, 2021).

Інформаційна функція.

Статутом УБА передбачено поширення інформації про діяльність організації, популяризацію її ідей і цілей (Статут громадської організації, 2018).

Інформаційна функція УБА проявляється, передусім, шляхом інформування членів організації про заходи, події, новини, проєкти тощо на офіційному веб-порталі асоціації; шляхом розсилки на е-адреси членів асоціації; інформування про новини у випусках бюлетеня Української бібліотечної асоціації «БібліоТека», фахових та профільних виданнях, у соціальних мережах, під час професійних форумів.

Офіційний веб-сайт Української бібліотечної асоціації був створений 1 березня 1998 р. О. Архипською (керівниця секції сучасних інформаційних технологій), В. Пашковою (президентка УБА), Т. Ярошенко (керівниця секції працівників університетських бібліотек) ("Хроніка подій", 1998).

Головна сторінка сайту дає можливість ознайомитись із новинами, отримати інформацію стосовно конференцій та семінарів, які відбулись, відбуваються та заплановані; інформацію про УБА (місія, принципи, історія, структура, хроніка подій, відзнаки); як стати членом УБА та переваги членства; про блоги асоціації; контакти тощо. Серед наявних рубрик сайту такі: документи (угоди про співпрацю, документи ІФЛА та ін., плани та звіти УБА тощо); членство; партнерство (як стати офіційним партнером, переваги, партнери); конференції, семінари, тренінги (програми освітніх заходів); Головний тренінговий центр (фотогалерея, ресурси, тренерський портал, навчальні матеріали семінарів та тренінгів, дистанційні курси тощо); програми, проєкти; секції, робочі групи; конкурси; нагороди та відзнаки; сервіси УБА; публікації (бюлетень, бібліографія, видання, PR-матеріали, сувеніри); ЗМІ про УБА; інформація для 3МI; волонтерство; ярмарок вакансій та працевлаштування; оголошення; навчальні матеріали семінарів та тренінгів; членський квиток УБА; професійні ресурси (Українська бібліотечна асоціація, 2021).

Сайт надає доступ до планово-звітної документації УБА, детально інформує про реалізацію форумів і проєктів, флеш-моби, акції та конкурси. Г. Хоменко звертає увагу на жанрову різноманітність презентованих на сайті УБА матеріалів. Згідно із представленими науковцем висновками, серед різновидів жанрів бібліо- 
течної журналістики на сайті наявні інформаційні звіти, інтерв’ю (з президентом УБА, членами президії, кожен із яких відповідає за певний напрям, з директорами бібліотек та бібліотечними працівниками тощо), аналітичні жанри, огляди інформації у ЗМІ про асоціацію, інформація про різноманітні заходи та семінари, які, за висновком Г. Хоменка, можна розглядати як кореспонденцію, статті, які інформують про зміни у галузі, матеріали рекомендаційного характеру, листи президента УБА до представників влади України тощо (Хоменко, 2015, с. 31-32).

Отже, представлений на сайті УБА великий масив інформації вчергове підтверджує тезу про відкритість асоціації, iї орієнтованість на оперативне і всебічне інформування своїх членів і широкої громадськості про свою діяльність.

Поширенню актуальної інформації стосовно діяльності УБА та актуальних питань розвитку бібліотечно-інформаційної сфери покликане сприяти налагодження випуску Бюлетеня Української бібліотечної асоціації «БібліоТека».

Бюлетень УБА був заснований у 2010 р., а перший випуск вийшов у червні того ж року. Сьогодні бюлетень видається чотири рази на рік та розповсюджується через регіональні відділення УБА, офіційний веб-сайт та останнім часом шляхом інформування членів асоціації на їх електронні адреси. Метою бюлетеня $\epsilon$ «реалізація комунікаційної політики УБА, інформування бібліотечних фахівців про діяльність УБА в цілому, іiї професійних секцій та регіональних відділень; висвітлення основних тенденцій і пріоритетних напрямів розвитку вітчизняного і міжнародного співтовариств; поширення інноваційних бібліотечних практик і просування успішного досвіду роботи українських бібліотек; сприяння розвитку професійних комунікацій та залучення бібліотекарів до членства в УБА» (Здановська, 2020).

Основні рубрики бюлетеня відображають діяльність асоціації та коло питань, якими вона займається, серед яких: «офіційні новини», «документи», «програмна діяльність», «актуально», «консолідуймося», «освіта і наука», «конкурси», «адвокаційна діяльність», «організаційний розвиток», «партнерство», «новини», «членство», «міжнародна співпраця», «із бібліотечного фольклору», «анонс», «проєкти», «хроніка подій», «конференції», «адвокація», «дослідження», «освіта, інновації», «безперервна освіта», «історія і сьогодення», «відзначаємо ювілей», «акції», «регіональні відділення УБА», «міжнародні новини», «відділення УБА», «світові тренди», «партнери УБА», «стратегічні орієнтири», «ініціативи», «бібліофорум», «кращі практики», «спільноДія» ("Бюлетень", 2021).

Загалом упродовж 2010-2021 рр. вийшов друком 41 номер бюлетеня (вересень 2021), у яких опубліковано понад 200 інформаційних повідомлень, оглядів, анонсів, звітів про діяльність щодо актуальних подій асоціації у певний період.

Інформування про УБА відбувається також шляхом підготовки наукових публікацій, у яких відображаються ті чи інші аспекти діяльності організації. Типовими у цьому контексті є наукові статті В. Пашкової (1996, 2006), В. Загуменної (2019), О. Воскобойнікової-Гузєвої (2018), І. Шевченко (2012), Я. Сошинської та I. Шевченко (2012) та ін.

Освітня функція.

У Статуті УБА серед видів діяльності, які здійснює асоціація, зазначаються організація та проведення «освітніх заходів для молодих бібліотекарів, у тому числі членів ГО «ВГО Українська бібліотечна асоціація», із залученням представників громадськості, органів державної влади та місцевого самоврядування, експертів 
із бібліотечної справи, у тому числі міжнародних експертів; ... сприяння підвищенню професіоналізму членів ГО «ВГО Українська бібліотечна асоціація», ...професійному і соціальному розвитку бібліотекарів, бібліографів та інформаційних працівників бібліотек усіх форм власності та підпорядкування, удосконаленню системи їх безперервної освіти» (Статут громадської організації, 2018).

Виразним проявом реалізації освітньої функції УБА стало створення 2009 р. в Інституті післядипломної освіти Національної академії керівних кадрів культури і мистецтв за проєктом УБА «Головного тренінгового центру» (ГТЦ) з метою реалізації концепції освіти протягом життя, адже центр передбачає підготовку навчальних програм підвищення кваліфікації працівників бібліотек, розробку навчальних матеріалів, дистанційних курсів, організацію курсового навчання тренерів для регіональних тренінгових центрів та в рамках підвищення кваліфікації бібліотекарів м. Київ та Київської області. Створення ГТЦ стало запорукою доступу бібліотечних працівників до навчально-методичних матеріалів різного тематичного спрямування з метою підвищення кваліфікації та опанування необхідних компетентностей.

Варто також згадати щорічні літні та зимові школи молодих бібліотекарів, які проходять за різними програмами з метою навчання молодих бібліотечних працівників та формування у них навичок сучасного бібліотечного фахівця; всеукраїнські школи бібліотечного журналіста; літні школи адвокації УБА для бібліотекарів тощо.

Щорічно під егідою УБА в партнерстві з провідними закладами вищої освіти, неурядовими організаціями, державними і приватними структурами проводяться майстер-класи, освітні семінари (вебінари) і тренінги, як-от майстер-клас «Будуємо карту стратегії бібліотеки» (18.12.2014 р., м. Київ); тренінги «Підліткове читання: щоб перше не було останнім» (12.03.2020 р., м. Київ), «Універсальні навички бібліотечного фахівця» (21.02.2020 р., м. Київ), «Можливості сервісних та пошукових чат-ботів. Створюємо прототип бота-бібліотекаря» (30.01.2020р., м. Київ), «Як планувати культурно-освітню діяльність бібліотеки без календаря визначних дат?» (17.10.2019 р., м. Київ), «Бібліотека в пошуку нових ідей» для бібліотекарів із Донецької та Луганської областей (21-23.06.2019 р., м. Дніпро), «Онлайн-сервіси для створення візуального контенту» (29.05.2019, м. Київ), «Практична медіаграмотність» (27-28.03.2015 р., м. Львів) та багато інших; семінари «Зведений каталог: чи стане реальністю для українських бібліотек?» (27.05.2021 р., онлайн-формат), німецько-український науково-практичний онлайновий семінар «Діяльність культурних інституцій: політика та фінансування» (19-20.04.2021 р.), семінар-тренінг «Усна історія: теорія і практика. Можливості бібліотек у долученні до створення усної історії», (01.04.2021 р., онлайн-формат), «Бібліотеки як центри підтримки громади в умовах воєнної загрози: робота із внутрішньо переміщеними особами (ВПО)», (6-10.10.2014 р., м. Київ) та ін.

Здійснення УБА освітньої функції в рамках розвитку бібліотечної справи в Україні набуває додаткового значення з огляду на скорочення обсягів підготовки студентів бібліотечних спеціальностей заочної форми навчання (наприклад, набір на 1-й курс заочної форми навчання студентів за спеціальністю 029 «Інформаційна, бібліотечна та архівна справа» вже декілька років відсутній у Харківський державній академії культури, практично відсутній - останній 2017 р. у кількості 14 студентів - у Київському національному університеті культури і 
мистецтв, хоча ці заклади вищої освіти є провідними в Україні в підготовці фахівців бібліотечних спеціальностей). Відповідно потреба організації підвищення кваліфікації бібліотечних працівників, оновлення ними своїх професійних компетентностей із метою відповідності сучасним вимогам лише зростає, що посилює значення освітнього напряму діяльності УБА.

Науково-методична функція.

Науково-методичний напрям діяльності УБА визначається їі Статутом, в якому, зокрема, ідеться про те, що УБА «сприяє обміну досвідом і підвищенню професійного рівня шляхом підготовки навчальних програм, організації курсів, стажувань і т. ін.; стимулює теоретичні дослідження і прикладні розробки у галузі бібліотечної справи, бібліографічної та інформаційної діяльності» (Cтатут громадської організації, 2018).

У рамках реалізації науково-методичної функції, згідно з даними офіційного веб-сайту Української бібліотечної асоціації, за період із 2010 по 2021 рік було підготовлено і видано близько 45 видань, серед яких: методичні рекомендації; практичні посібники; посібники для тренерів та бібліотекарів із програмою підвищення кваліфікації; навчальні матеріали для підвищення кваліфікації бібліотекарів; збірники матеріалів конференцій та ін. (Українська бібліотечна асоціація, 2021).

Лише протягом 2020-2021 pр. було підготовлено і видано науково-методичний порадник «Участь бібліотек у реалізації політики національної пам’яті» (Київ: УБА, 2021), практичний посібник «Чотири простори бібліотеки: модель діяльності» (Київ: УБА, 2020), рекомендації «Процес якісної інформаційної підтримки освіти та досліджень у бібліотеці університету» (Київ: УБА, 2020), програми навчальних модулів підвищення кваліфікації працівників бібліотек «АБІС Коһа та створення електронного каталогу в бібліотеках закладів вищої освіти» (Київ: УБА, 2020), «Університетська бібліотека в системі наукових комунікацій» (Київ: УБА, 2020).

У доробку УБА розробка таких досі актуальних матеріалів, як методичні поради «Навчання студентів академічній доброчесності у бібліотеці ВНЗ» (Київ : УБА, 2016), методичні рекомендації «Міжнародні правила цитування та посилання в наукових роботах» (Київ : УБА, 2016), посібники для тренерів за програмою підвищення кваліфікації «Адвокація: представлення інтересів бібліотек» (Київ : Самміт-книга, 2012) та «Технології Веб 2.0 для бібліотек і користувачів: нові можливості розвитку бібліотечного середовища» (Київ : Самміт-книга, 2012).

Слід наголосити, що згадані матеріали з'явились ще тоді, коли в закладах вищої освіти з підготовки бібліотечних фахівців відповідних курсів не було розроблено. Тобто УБА, беручи до уваги потреби практичної діяльності бібліотек, виступила ініціатором та заклала науково-методичне підгрунтя підготовки і впровадження бібліотечних і освітніх інновацій, певною мірою компенсуючи в такий спосіб брак відповідних напрацювань у бібліотеках і закладах вищої освіти.

Представницька функція.

ВГО Українська бібліотечна асоціація є організацією, яка взаємодіє з владою та різними структурами громадянського суспільства від імені всіх бібліотечних працівників і фахівців, дотичних до бібліотечної справи, представляючи та обстоюючи ї інтереси. В Україні та за кордоном УБА представляє вітчизняних бібліотечних фахівців як спільноту. 
У Статуті УБА зазначається, що організація поширює свою діяльність на всю територію України, їі членами можуть бути представники будь-яких бібліотек («особи, які професійно пов’язані з бібліотечною справою, бібліографічною й інформаційною діяльністю») (Статут громадської організації, 2018).

Організована на демократичних засадах, УБА надає змогу своїм членам брати участь в управлінні організацією - обирати і бути обраними до керівних органів УБА, брати участь у Конференціях ВГО Українська бібліотечна асоціація і голосувати під час ухвалення рішень та методом опитування, ініціювати розгляд асоціацією та іiі керівними органами окремих питань, пов’язаних із цілями та завданнями УБА, брати участь у реалізації різних напрямів діяльності асоціації, іiі заходах, користуватися іiї продуктами і послугами. Вищим керівним органом ВГО

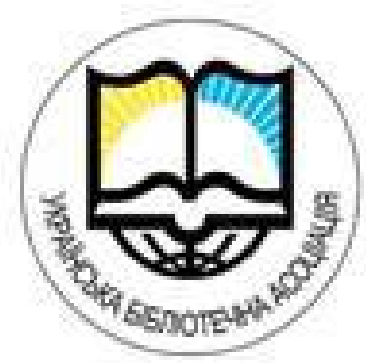

Puc. 1. Логотип ВГО Українська бібліотечна асоціація до 2021 p. Джерело: https://ula.org. ua/259-publikaciyi/prmateriali/1731-502-502-prmateriali. Українська бібліотечна асоціація Статут визначає Конференцію її членів, яка може бути звітно-виборною, робочою і надзвичайною (Статут громадської організації, 2018).

Відповідно, на організаційному рівні УБА було закладено підгрунтя для здійснення функції ефективного представництва бібліотечної спільноти України.

Виконанню представницької функції УБА сприяє забезпечення впізнаваності організації через вдале поєднання її позиціонування та айдентики, передусім, логотипу (див. рис. 1).

2021 р. асоціацією було проведено ребрендинг і осучаснено її корпоративний стиль (див. рис. 2.).

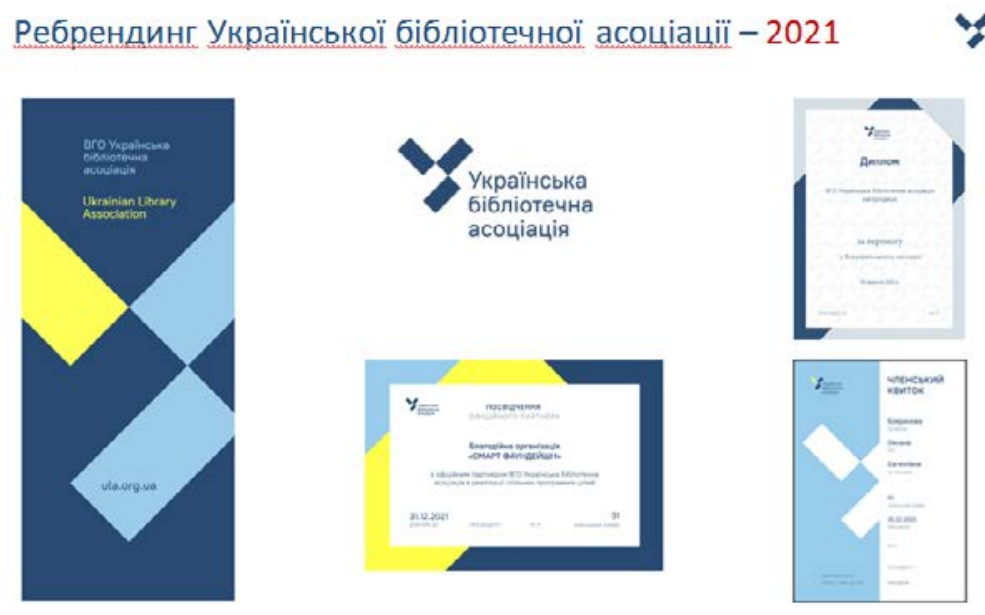

Puc. 2. Новий корпоративний стиль і логотип ВГО Українська бібліотечна асоціація (2021р.).

Джерело: Об’єднуємось заради досягнення спільних цілей. Реалізація Стратегії Української бібліотечної асоціації 2019-2021 рр.: звіт Президії ВГО Українська бібліотечна асоціація на щорічній та звітно-виборній Конференції 17 листопада 2021 p.

[Презентація]. с. 121. 
Свій логотип був розроблений також Молодіжною секцією УБА (див. рис. 3).

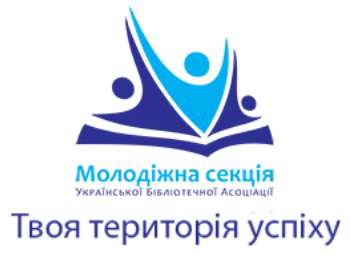

Puc. 3. Логотип Молодіжної секції ВГО Українська бібліотечна асоціація. Джерело: https://cutt.ly/QmdLOPz.

Щорічно УБА візуалізує обраний девіз, який, зазвичай, розміщується на матеріалах УБА, а також закладинках, банерах та плакатах (див. рис. 4).

\section{БІБЛ ТЕКА - твоЯ тоUKA OחOPИ}
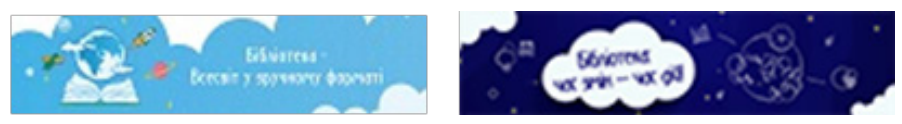

Рис. 4. Візуалізація девізів УБА 2021, 2020 та 2019 років (зліва направо). Джерело: https://ula.org.ua/259-publikaciyi/pr-materiali.

Крім того, для окремих заходів та проєктів УБА також спеціально розробляється унікальна символіка, яка дає змогу їх ідентифікувати і дізнатися про участь УБА. Зокрема, це стосується логотипу Львівського бібліотечного форуму, візуальних матеріалів у рамках проєктів «Культура академічної доброчесності: роль бібліотек», «Читай! Формат не має значення!» (див. рис. 5).

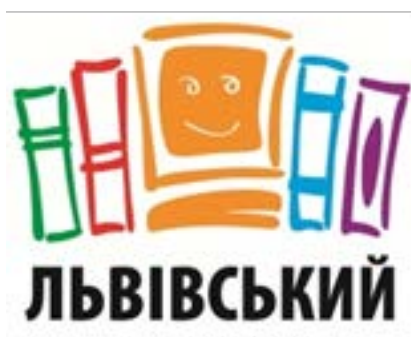

БІБЛІОТЕЧНИЙ ФОРУМ
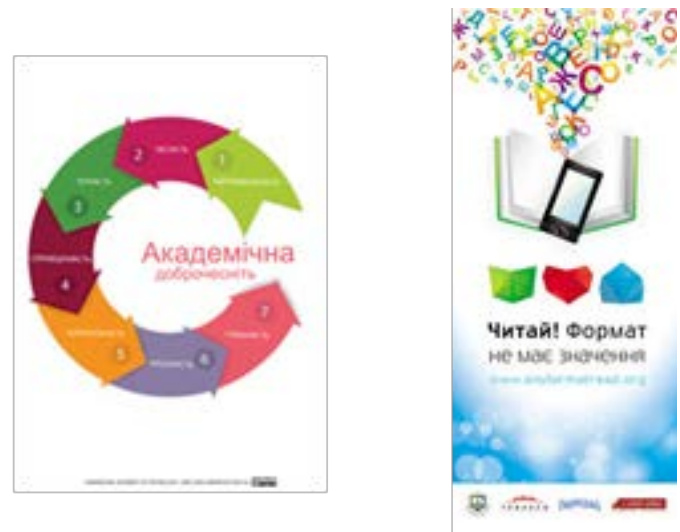

Puc. 5. Зліва направо: логотип Львівського бібліотечного форуму, листівка проєкту «Культура академічної доброчесності: роль бібліотек», плакат проєкту «Читай! Формат не має значення!». Джерела: https://cutt.ly/mmdKB2v; https://cutt.ly/1mdNzbJ; https://cutt.ly/2mdMYog.

Адвокаційна функція.

Статутом УБА серед інших видів діяльності організації передбачено можливість для УБА «вносити пропозиції до органів державної влади та органів місце- 
вого самоврядування щодо вирішення проблемних питань стосовно бібліотечної справи; ...вживати заходи щодо привернення уваги широкого кола громадськості для вирішення проблем, які стосуються бібліотечної справи; ...підтримувати ініціативи громадських рухів, установ та організацій, програми народних депутатів, спрямовані на розвиток культури та бібліотечної справи; ...організовувати соціальний захист бібліотекарів, бібліографів та інформаційних працівників, сприяти поліпшенню умов їх праці та побуту, встановленню належної оплати їх праці і пенсійного забезпечення, зміцненню професійної солідарності» (Cтатут громадської організації, 2018).

Усі ці види діяльності охоплюються поняттям бібліотечної адвокації - комплексної систематичної діяльності, скерованої на представництво та захист інтересів бібліотек, бібліотекарів і користувачів, на отримання підтримки та розуміння з боку влади, громади і суспільства загалом; заходи з позиціонування, просування бібліотек як важливого соціального інституту та підвищення іміджу і ролі книгозбірень у суспільстві (Загуменна, 2020).

Для ефективного виконання адвокаційної функції 2008 р. у структурі УБА було створено секцію з адвокації. На порталі асоціації представлено видання за тематикою адвокації, зокрема, «Адвокація: представлення інтересів бібліотек: посіб. для тренерів за прогр. підвищ, кваліфікації» (2012); «Законодавство України на допомогу адвокаційній діяльності бібліотек: збірка документів» (2012) та ін. (Українська бібліотечна асоціація, 2021).

3 метою підвищення ефективності адвокаційного напряму діяльності УБА секцією було розроблено Програму УБА з адвокації на 2017-2021 рр. «Дієва бібліотека - успішна громада!» (Дієва бібліотека - успішна громада, 2016), яка обговорювалась під час Всеукраїнської літньої школи з адвокації (червень 2016 р.), Львівського бібліофоруму (вересень 2016 р.) та Всеукраїнської конференції УБА (листопад 2016 р.) i, зрештою, була схвалена до виконання. Документ спрямований на «лобіювання та захист прав користувачів бібліотек територіальних громад на бібліотечне обслуговування та безперешкодний і рівноправний доступ до інформації, обстоювання їхніх прав в умовах суспільних перетворень та об'єднання територіальних громад; позиціонування бібліотек у суспільстві як відкритого простору для освіти, науки, культури, дозвілля, комунікації та підвищення обізнаності членів громади, влади, суспільства в цілому про цінність та потенціал бібліотек у здійсненні реформ» (Дієва бібліотека, 2016, с. 1).

Програмою було визначено три стратегічні цілі:

- $\quad$ сприяння впровадженню нових соціальних нормативів бібліотечного обслуговування в умовах утворення об’єднаних територіальних громад (ОТГ);

- формування модельних стандартів бібліотечного обслуговування та розроблення рекомендацій щодо їх впровадження в умовах адміністративної реформи з урахуванням процесів інтеграції бібліотечних мереж, культурних інституцій, освітніх установ;

- підвищення обізнаності кожної територіальної громади про потенціал і можливості бібліотеки в суспільних перетвореннях шляхом ефективних комунікацій, PR та реклами (Дієва бібліотека, 2016, с. 1). 
На виконання Програми було розроблено і ухвалено відповідний План дій, який передбачав здійснення заходів із досягнення кожної з програмних цілей (План дій, 2017).

Під час проведення в Україні реформи децентралізації та створення об'єднаних територіальних громад (ОТГ), яка супроводжувалася загостренням потреби захисту бібліотек від закриття місцевою владою, УБА готувала і готує листи та звернення до профільного Міністерства і представників місцевого самоврядування, в яких наголошує на необхідності дотримання чинного законодавства під час реорганізації бібліотечної мережі, погодження питань стосовно закриття бібліотек із Міністерством культури та інформаційної політики України, захисту прав працівників бібліотек під час ліквідації або реорганізації бібліотечних закладів (зокрема, у 2020 р. УБА підготувала відповідний Відкритий лист районним, міським, селищним та сільським радам щодо реорганізації мережі публічних бібліотек; Міністерству культури та інформаційної політики України «Щодо реорганізації мережі публічних бібліотек» ("Відкритий лист районним", 2020) в умовах, спричинених пандемією COVID-19, - звернення стосовно забезпечення безпечного відновлення роботи бібліотек ("Звернення ВГО", 2020), і т. ін.

Ефективним інструментом поширення ефективних адвокаційних практик стали організовані УБА літні школи з адвокації.

Компенсаторна функція.

Реалізація компенсаторної функції, як можна зрозуміти з назви, полягає в заповненні нестачі (компенсації) як загальнодержавних, так і регіональних, локальних рішень і політик стосовно розвитку окремих напрямів бібліотечної справи в Україні, діяльності бібліотек та здійснення ними своїх соціальних функцій.

Від початку реалізація компенсаторної функції не була передбачена статутними документами УБА, разом із тим вона виразно проявилась, наприклад, під час залучення бібліотек до формування культури академічної доброчесності: в умовах відсутності напрацьованих керівних документів загальнодержавного рівня, що стосувалися питання дотримання принципів академічної доброчесності, УБА надала бібліотекам необхідне теоретичне та практичне підгрунтя для ефективної участі у сприянні формуванню культури академічної доброчесності. Нагадаємо, що на законодавчому рівні Закон України «Про освіту» із присвяченою академічній доброчесності статтею 42 був ухвалений у 2017 р., проєкт «Ініціатива академічної доброчесності та якості освіти», який впроваджувався в українських школах і закладах вищої освіти Американськими Радами з міжнародної освіти за сприяння Посольства США в Україні та підтримки Міністерства освіти і науки України і Національного агентства із забезпечення якості вищої освіти, реалізовувався у 2020 р., тоді як УБА розпочала проєкт «Культура академічної доброчесності: роль бібліотек» ще 2016 р. Тобто навіть до того, як проблема дотримання принципів академічної доброчесності в науково-освітньому середовищі була формалізована на законодавчому рівні.

\section{ВИСНОВКИ}

Створення УБА було обумовлено потребою вирішення певних завдань та реалізації ряду функцій як стосовно розвитку вітчизняної бібліотечної справи, так і суспільства в цілому. Як відкрита адаптивна лідерська громадська організація, ВГО Українська бібліотечна асоціація реалізує під час своєї діяльності такі функції, як: 
- організаційно-консолідуюча, яка проявилась у створенні УБА, заснуванні їі відділень, розбудові структури, консолідації на платформі асоціації лідерського потенціалу вітчизняних фахівців бібліотечної справи;

- мобілізаційно-мотивуюча, яка реалізується шляхом залучення бібліотечної спільноти до участі в проєктах, грантах, флешмобах, тренінгах тощо через підтримку і заохочення активної професійної і громадянської позиції та ініціативи;

- комунікаційно-координаційна, здійснення якої передбачає формування середовища професійної комунікації в оффлайн і онлайн форматах і забезпечує багатосторонній обмін інформацією поміж керівними органами УБА, відділеннями асоціації, її рядовими членами, створюючи умови для оперативного ухвалення рішень і узгодження дій;

мації стосовно діяльності УБА та її керівних органів, ключових тенденцій розвитку бібліотечної справи, прогресивного досвіду практичної діяльності бібліотек, важливих урядових ініціатив тощо через офіційний веб-сайт УБА, бюлетень Української бібліотечної асоціації «БібліоТека», масову розсилку електронною поштою, публікацію повідомлень у соціальних мережах та інформування під час профільних форумів;

- освітня, яка спрямована на підвищення кваліфікації бібліотечних працівників та набуття ними нових потрібних для забезпечення ефективного бібліотечно-інформаційного сервісу навичок;

- науково-методична, яка полягає в концептуальному оформленні й теоретичному обгрунтуванні перспективних напрямів розвитку бібліотечної справи в Україні, розробці методичного забезпечення реалізації цих напрямів;

- представницька, яка передбачає представлення вітчизняної професійної бібліотечної спільноти у відносинах з органами державної влади та структурами громадянського суспільства, а також із зарубіжними й міжнародними організаціями та установами;

- адвокаційна, спрямована на захист і промоцію інтересів бібліотек, бібліотечної спільноти та користувачів, формування позитивного іміджу бібліотек і підвищення престижу бібліотечної професії;

- компенсаторна, призначенням якої $є$ забезпечення бібліотекам необхідного теоретичного та практичного підгрунтя для ефективної реалізації перспективних напрямів діяльності в умовах відсутності відповідних ухвалених керівних документів загальнодержавного рівня.

\section{СПИСОК ПОСИЛАНЬ}

Бабич В. С., Сошинська Я. Є. Установча конференція Української бібліотечної асоціації. Бібліотечний вісник. 1995. № 3. С. 16-18.

Бюлетень. Українська бібліотечна асоціація. URL: https://ula.org.ua/259-publikaciyi/byuleten (дата звернення: 28.05.2021).

Відкритий лист районним, міським, селищним та сільським радам щодо реорганізації мережі публічних бібліотек, м. Київ, 28 грудня 2020 р. (30.12.2020). Українська бібліотечна асоціація. URL: https://cutt.ly/9nRYwnH (дата звернення: 09.06.2021). 
Воскобойнікова-Гузєва О. В. Вебінар як засіб реалізації освітніх проектів громадської організації. Відкрите освітнє е-середовище сучасного університету. 2018. Вип. 5. С. 51-57. URL: http://irbis-nbuv.gov.ua/everlib/item/er-0002568(дата звернення: 17.10.2021).

Дієва бібліотека - успішна громада: програма адвокаційної діяльностіУкраїнської бібліотечної асоціації на 2017-2021 pр. / розроб.: Агаркова В. В., Барабаш С. І., Варюхіна Л. М. та ін. ; Укр. бібл.асоц. URL: https://cutt.ly/8md9PКР (дата звернення: 17.10.2021).

До Всеукраїнського дня бібліотек презентували відео «Бібліотечний рок-н-рол». Еспресо. 30 верес. 2020. URL: https://cutt.ly/DnjqC1m (дата звернення: 01.06.2021).

Добко Т. Бібліотечні асоціації. Енциклопедія Сучасної України. Київ, 2003. Т. 2. С. 734-735.

Добко Т. В., Загуменна В. В. Засідання бібліографічної секції Української бібліотечної асоціації. Бібліотечний вісник. 1996. № 5. С. 31-32.

Загуменна В. В. Адвокація як важливий напрям діяльності сучасної бібліотеки. Вісник Книжкової палати. 2019. № 4. С. 25-28.

Загуменна В. В. Адвокація. Українська бібліотечна енциклопедія. 2020. URL: https://cutt.ly/ Wmd2oXQ (дата звернення: 27.05.2021).

Загуменна В. В. Участь публічних бібліотек у роботі бібліографічної секції Української бібліотечної асоціації. Публічні бібліотеки: сучасність і майбутнє : зб. ст. до Міжнар. наук.-практ. конф. / УБА та ін. Київ, 1997. С. 75-79.

Запрошуємо бібліотеки України приєднатись до бібліотечного радіофлешмобу «Good Silent Party» (15.12.2016). Українська бібліотечна асоціація. URL: https://cutt.ly/jTQfeEJ (дата звернення: 08.06.2021).

Звернення ВГО Українська бібліотечна асоціація щодо COVID-19 (17.03.2020). Українська бібліотечна асоціація. URL: https://cutt.ly/hhtga8t (дата звернення: 21.11.2020).

Здановська В. П. БібліоТека. Бюлетень Української бібліотечної асоціації. Українська бібліотечна енциклопедія. 30.01.2020. URL: https:/cutt.ly/hnivNaS (дата звернення: 27.05.2021).

Ковальчук Л. І. Українська бібліотечна асоціація на захисті інтересів бібліотек. БібліоТек@. 2010. Липень. С. 1-2. URL: https://cutt.ly/0tI0oHm (дата звернення: 15.02.2020).

Мотивація. Вікіпедія. 11 листоп. 2021. URL: https:/cutt.ly/ZTQQ0Tj (дата звернення: 27.05.2021).

Падалка Г. VII Львівський міжнародний бібліотечний форум «Модерн@ бібліотека в мінливому світі». Інститут журналістики Київського університету імені Бориса Грінченка. 2016. URL: https://cutt.ly/Dmc0hbS (дата звернення: 17.10.2021).

Пашкова В. Внесок національних бібліотечних асоціацій у формування іміджу бібліотеки в суспільстві й підвищення престижу бібліотечної професії. Бібліотечний форум України. 2007а. № 1. С. 50-56.

Пашкова В. Внесок професійних бібліотечних об’єднань у безперервну освіту. Бібліотечна планета. 2007b. № 3. С. 10-15.

Пашкова В.Дванадцять років програмам бібліотечних обмінів із США. Бібліотечна планеma. 2005. № 1. С. 14-15.

Пашкова В. С. Еволюція національних бібліотечних асоціацій (1876-2009) : автореф. дис. ... д-ра іст. наук : 27.00.03. Київ, 2010а. 40 с.

Пашкова В. С. Міжнародний семінар «Нові бібліотечні стратегії». Бібліотечний вісник. 1996. № 4. C. 33-34.

Пашкова В. Новини, тенденції. Бібліотечна планета. 2006. № 4. С. 32-33.

Пашкова В. С. Нові проекти: інформаційна грамотність, електронні бібліотеки, розвиток книжкових колекцій. Бібліотечна планета. 2006. № 2. С. 23.

Пашкова В. С. Українська бібліотечна асоціація: аналіз реалізації стратегічних напрямів розвитку в 2006-2009 роках. Вісник Книжкової палати. 2010b. № 2. С. 19-25.

План дій щодо реалізації програми адвокаційної діяльності УБА на 2017-2021 роки «Дієва бібліотека - успішна громада» : затв. Президією УБА, протокол № 8 від 6 груд. 2017 р. 
/ розроб.: Шевченко I., Лугова Л., Барабаш С. та ін. URL: https://cutt.ly/pmd4kOg (дата звернення: 17.10.2021).

Плахтій А. М. Публічні бібліотеки в системі інформаційно-комунікаційного забезпечення електронного урядування в Україні : дис. ... канд. наук із соц. комунікацій : 27.00.03 / Київ. нац. ун-т культури і мистецтв. Київ, 2021. 245 с.

Про схвалення Стратегії розвитку бібліотечної справи на період до 2025 року «Якісні зміни бібліотек для забезпечення сталого розвитку України» : Розпорядження Кабінету Міністрів України від 23.03.2016 р. № 219-p. URL: https:/cutt.ly/zTIE0tS (дата звернення: 21.10.2021).

Сошинська Я. Українська бібліотечна асоціація на 17-й Міжнародній Конференції «Крим 2010».БібліоТек@. 2010. Червень. С. 3. URL: https://cutt.ly/1TQWypQ (дата звернення: 17.10.2021).

Сошинська Я., Шевченко І. Бібліотечна подія року - конференція Української бібліотечної асоціації. Бібліотечна планета. 2012. № 4. С. 30-31.

Статут громадської організації «Всеукраїнська громадська організація Українська бібліотечна асоціація» (нова редакція). Українська бібліотечна асоціація. URL: https://cutt. ly/TmdDDG7 (дата звернення: 17.10.2021).

Трач Ю. В. Професійний розвиток бібліотекарів у фахових об’єднаннях України : дис. ... канд. пед. наук : 07.00.08 / Київ. нац. ун-т культури і мистецтв. Київ, 2001. 212 с.

У Львові відбудеться Х Львівський міжнародний бібліотечний форум. Агенція інформації та аналітики «Гал-інфо». 11 вересня 2019. URL: https://cutt.ly/dTQsUCr (дата звернення 17.10.2021).

Українська бібліотечна асоціація. PR-матеріали. Українська бібліотечна асоціація. URL: https://cutt.ly/aTQWbHf (дата звернення 28.05.2021).

Українська бібліотечна асоціація. Видання. Українська бібліотечна асоціація. URL: https:// cutt.ly/zyYbztf (дата звернення: 08.06.2021 р.).

Українська бібліотечна асоціація: офіц. веб-сайт. Українська бібліотечна асоціація. URL: https://ula.org.ua/ (дата звернення 28.05.2021).

Хоменко Г. Ю. Веб-сайт Української бібліотечної асоціації у дзеркалі жанрів бібліотечної журналістики. Бібліотека в цифровому медіасвіті: присвячується 20-літтю Української бібліотечної асоціації: матеріали Всеукр. студ. наук.-практ. конф., 25 верес. 2015 р. / уклад.: М. В. Макарова, Л. С. Прокопенко, В. Є. Сошинська. Київ, 2015. C. 30-33. URL: https://cutt.ly/oTQWgiD (дата звернення 17.10.2021).

Хроніка подій - 1998. Українська бібліотечна асоціація. URL: https://cutt.ly/8tI91Kt (дата звернення: 15.02.2020).

Шевченко І. Міжнародна співпраця - важливий напрям роботи Української бібліотечної асоціації (нотатки зФоруму бібліотекарів у Астані). Бібліотечна планета. 2012. № 4. C. 6-8.

Шендрик О. О. Міжнародне співробітництво публічних бібліотек України (90-ті pp. ХХ ст. поч. XXI ст.) : дис.... канд. наук із соц. комунікацій : 27.00.03 / Київ. нац. ун-т культури і мистецтв. Київ, 2018. 225 с.

\section{REFERENCES}

Babych, V. S., \& Soshynska, Ya. Ye. (1995). Ustanovcha konferentsiia Ukrainskoi bibliotechnoi asotsiatsii [Constituent Conference of the Ukrainian Library Association]. Bibliotechnyi Visnyk, 3, 16-18 [in Ukrainian].

Ukrainian Library Association. (n.d.). Biuleten [Bulletin]. https://ula.org.ua/259-publikaciyi/ byuleten [in Ukrainian]. 
Ukrainian Library Association. (2020, December 30). Vidkrytyi lyst raionnym, miskym, selyshchnym ta silskym radam shchodo reorhanizatsii merezhi publichnykh bibliotek, $m$. Kyiv, 28 hrudnia 2020 r. [Open Letter to District, City, Settlement and Village Councils on the Reorganization of the Network of Public Libraries, Kyiv, December 28, 2020]. https://cutt.ly/9nRYwnH [in Ukrainian].

Voskoboinikova-Huzieva, O. V. (2018) Vebinar yak zasib realizatsii osvitnikh proektiv hromadskoi orhanizatsii [Webinaras a means of implementing educational projects of public organization]. Open Educational E-environment of Modern University, 5, 51-57. http://irbisnbuv.gov.ua/everlib/item/er-0002568 [in Ukrainian].

Aharkova, V. V., Barabash, S. I., Variukhina, L. M., Vlezko, N. V., Zahumenna, V. V., Luhova, L. A., Moisieieva, S. A., Synytsia, N. M., Spanchak, T. I., Tkachenko, O. V., \& Shevchenko, I. O. Diieva biblioteka - uspishna hromada: prohrama advokatsiinoi diialnosti Ukrainskoi bibliotechnoi asotsiatsii na 2017-2021 rr. [An Effective Library is a Successful Community: The Advocacy Program of the Ukrainian Library Association for 2017-2021]. https://cutt. ly/8md9PKP [in Ukrainian].

Espreso. (2020, September 30). Do Vseukrainskoho dnia bibliotek prezentuvaly video "Bibliotechnyi rok-n-rol" [For the All-Ukrainian Day of Libraries, the Video "Library Rock and Roll" Was Presented]. https://cutt.ly/DnjqC1m [in Ukrainian].

Dobko, T. (2003). Bibliotechni asotsiatsii [Library Assosiations]. In Encyclopedia of Modern Ukraine (Vol. 2, pp. 734-735). Institute of Encyclopedic Research of the National Academy of Sciences of Ukraine [in Ukrainian].

Dobko, T. V., \& Zahumenna, V. V. (1996). Zasidannia bibliohrafichnoi sektsii Ukrainskoi bibliotechnoi asotsiatsii [Meeting of the bibliographic section of the Ukrainian Library Association]. Bibliotechnyi Visnyk, 5, 31-32 [in Ukrainian].

Zahumenna, V. V. (2019). Advokatsiia yak vazhlyvyi napriam diialnosti suchasnoi biblioteky [Advocacy as an important activity of a modern library]. Bulletin of the Book Chamber, 4, 25-28 [in Ukrainian].

Zahumenna, V. V. (2020, January 14). Advokatsiia [Advocacy]. In Ukrainska Bibliotechna Entsyklopediia. https://cutt.ly/Wmd2oXQ [in Ukrainian].

Zahumenna,V.V.(1997). Uchast publichnykh bibliotek u roboti bibliohrafichnoi sektsii Ukrainskoi bibliotechnoi asotsiatsii [Participation of public libraries in the work of the bibliographic section of the Ukrainian Library Association]. In V. S. Pashkova (Ed.), Publichni biblioteky: suchasnist i maibutnie [Public Libraries: Present and Future], Proceedings of the International Scientific and Practical Conference (pp. 75-79). Ukrainian Library Association [in Ukrainian].

Ukrainian Library Association. (2016, December 15). Zaproshuiemo biblioteky Ukrainy pryiednatys do bibliotechnoho radio fleshmobu "Good Silent Party" [We Invite Libraries of Ukraine to Join the Library Radio Flashmob "Good Silent Party"]. https://cutt.ly/jTQfeEJ [in Ukrainian].

Ukrainian Library Association. (2020, March 17). Zvernennia VHO Ukrainska bibliotechna asotsiatsiia shchodo COVID-19 [Address of the Ukrainian Library Association Regarding COVID-19]. https://cutt.ly/hhtga8t [in Ukrainian].

Zdanovska, V. P. (2020, January 30). BiblioTeka. Biuleten Ukrainskoi bibliotechnoi asotsiatsii [Library. Bulletin of the Ukrainian Library Association]. In Ukrainska Bibliotechna Entsyklopediia. https://cutt.ly/hnivNaS [in Ukrainian].

Kovalchuk, L. I. (2010). Ukrainska bibliotechna asotsiatsiia na zakhysti interesiv bibliotek [Ukrainian library association on behalf of the interests of libraries].BiblioTek@, Juli, 1-2. https://cutt.ly/LtSqKlj [in Ukrainian].

Motyvatsiia [Motivation]. (2021, November 11). In Wikipediia. https://cutt.ly/ZTQQ0Tj [in Ukrainian]. 
Padalka, H. (2016).VII Lvivskyi mizhnarodnyi bibliotechnyi forum "Modern@ biblioteka v minlyvomu sviti" [VII Lviv International Library Forum "Modern@Library in a Changing World"]. https:// cutt.ly/Dmc0hbS [in Ukrainian].

Pashkova, V. (2007). Vnesok natsionalnykh bibliotechnykh asotsiatsii u formuvannia imidzhu biblioteky v suspilstvi i pidvyshchennia prestyzhu bibliotechnoi profesii [The contribution of national library associations to the image of the library in society in raising the prestige of the library profession]. Bibliotechnyi Forum Ukrainy, 1, 50-56 [in Ukrainian].

Pashkova, V. (2007). Vnesok profesiinykh bibliotechnykh obiednan u bezperervnu osvitu [Contribution of professional library associations to continuing education]. Bibliotechna Planeta, 3, 10-15 [in Ukrainian].

Pashkova, V. (2005). Dvanadtsiat rokiv prohramam bibliotechnykh obminiv iz SShA [Twelve years of library exchange programs from the United States]. Bibliotechna Planeta, 1, 14-15 [in Ukrainian].

Pashkova, V. S. (2010). Evoliutsiia natsionalnykh bibliotechnykh asotsiatsii (1876-2009) [Evolution of National Library Associations (1876-2009)] [Abstract of DSc Dissertation, Vernadsky National Library of Ukraine] [in Ukrainian].

Pashkova, V. S. (1996). Mizhnarodnyi seminar "Novi bibliotechni stratehii" [International seminar "New librarys trategies"]. Bibliotechnyi Visnyk, 4, 33-34 [in Ukrainian].

Pashkova, V. (2006). Novyny, tendentsii [News, trends]. Bibliotechna Planeta, 4, 32-33 [in Ukrainian].

Pashkova, V. S. (2006). Novi proekty: informatsiina hramotnist, elektronni biblioteky, rozvytok knyzhkovykh kolektsii [New projects: information literacy, electronic libraries, development of book collections]. Bibliotechna Planeta, 2, 23 [in Ukrainian].

Pashkova, V. S. (2010). Ukrainska bibliotechna asotsiatsiia: analiz realizatsii stratehichnykh napriamiv rozvytku v 2006-2009 rokakh [Ukrainian Library Association: Analysis of Implementation of Strategic Directions for Developmentin 2006-2009]. Bulletin of the Book Chamber, 2, 19-25.

Shevchenko, I., Luhova, L., Barabash, S., Moisieieva, S., Vlezko, N., Mozghova, L., Titova, N., \& Synytsia, N. (2017, December 6). Plan dii shchodo realizatsii prohramy advokatsiinoi diialnosti UBA na 2017-2021 roky "Diieva biblioteka - uspishna hromada" [Action Plan for the Implementation of the UBA Advocacy Program for 2017-2021 "Effective Library - a Successful Community"]. Ukrainska bibliotechna asotsiatsiia. https://cutt.ly/pmd4kOg [in Ukrainian].

Plakhtii, A.M.(2021). Publichni biblioteky v systemi informatsiino- komunikatsiinoho zabezpechennia elektronnoho uriaduvannia $v$ Ukraini [Public Libraries in the System of Information and Communication Support of Electronic Government in Ukraine] [PhD Dissertation, Kyiv National University of Culture and Arts] [in Ukrainian].

Cabinet of Ministers of Ukraine. (2016, March 23). Pro skhvalennia Stratehii rozvytku bibliotechnoi spravy na period do 2025 roku "Iakisni zminy bibliotek dlia zabezpechennia staloho rozvytku Ukrainy" [On approval of the Strategy for the development of librarianship for the period up to 2025 "Qualitative changes in libraries to ensure sustainable development of Ukraine"] (№ 219). https://cutt.ly/zTIE0tS [in Ukrainian].

Soshynska, Ya. (2010). Ukrainska bibliotechna asotsiatsiia na 17-i Mizhnarodnii Konferentsii "Krym 2010" [Ukrainian Library Association at the 17th International Conference "Crimea 2010”].BiblioTek@, Juni, 3. https://cutt.ly/1TQWypQ [in Ukrainian].

Soshynska, Ya., \& Shevchenko, I. (2012). Bibliotechna podiia roku - konferentsiia Ukrainskoi bibliotechnoi asotsiat sii [Library event of the year-conference of the Ukrainian Library Association]. Bibliotechna Planeta, 4, 30-31 [in Ukrainian].

Ukrainian Library Association. (2018, November 22). Statut hromadskoi orhanizatsii "Vseukrainska hromadska orhanizatsiia Ukrainska bibliotechna asotsiatsiia" [Charter of the Public Organization" All-Ukrainian Public Organization Ukrainian Library Association"]. https:// cutt.ly/TmdDDG7 [in Ukrainian]. 
Trach, Yu. V. (2001). Profesiinyi rozvytok bibliotekariv u fakhovykh obiednanniakh Ukrainy [Professional Development of Librarians in Professional Associations of Ukraine] [PhD Dissertation, Kyiv National University of Culture and Arts] [in Ukrainian].

Galinfo. (2019, September, 11). U Lvovi vidbudetsia X Lvivskyi mizhnarodnyi bibliotechnyi forum [The 10th Lviv International Library Forum Will Take Place in Lviv]. https://cutt.ly/dTQsUCr [in Ukrainian].

Ukrainian Library Association. (n.d.). Ukrainska bibliotechna asotsiatsiia. PR - materialy [Ukrainian Library Association. PR-materials]. https://cutt.ly/aTQWbHf [in Ukrainian].

Ukrainian Library Association. (n.d.). Ukrainska bibliotechna asotsiatsiia. Vydannia [Ukrainian Library Association. Publications]. https://cutt.ly/zyYbztf [in Ukrainian].

Ukrainian Library Association. (n.d.). Ukrainska bibliotechna asotsiatsiia [Ukrainian Library Association]: Official website. https://ula.org.ua/ [in Ukrainian].

Khomenko, H. Yu. (2015, September 25). Veb-sait Ukrainskoi bibliotechnoi asotsiatsii u dzerkali zhanriv bibliotechnoi zhurnalistyky [Website of the Ukrainian Library Association in the Mirror of Library Journalism Genres]. In M. V. Makarova, L. S. Prokopenko, \& V. Ye. Soshynska (Comps.), Biblioteka v tsyfrovomu mediasviti [Library in Digital Media Education]: Dedicated to the 20th Anniversary of the Ukrainian Library Association, Proceedings of the All-Ukrainian Scientific and Practical Conference, Kyiv, Ukraine. https://cutt.ly/oTQWgiD [in Ukrainian].

Ukrainian Library Association. (1998). Khronika podii -1998 [Chronicle of Events -1998]. https:// cutt.ly/8tI9lKt [in Ukrainian].

Shevchenko, I. (2012). Mizhnarodna spivpratsia - vazhlyvyi napriam roboty Ukrainskoi bibliotechnoi asotsiatsii (notatky z Forumu bibliotekariv u Astani) [International cooperation is an important direction of the work of the Ukrainian LibraryAssociation (notes from the Forum of Librarians in Astana)]. Bibliotechna Planeta, 4, 6-8 [in Ukrainian]. Shendryk, O. O. (2018). Mizhnarodne spivrobitnytstvo publichnykh bibliotek Ukrainy (90-ti rr. XX st. - poch. XXI st.) [International Cooperation of Public Libraries of Ukraine (the 1890sBeginning of the 21st Century] [PhD Dissertation, Kyiv National University of Culture and Arts] [in Ukrainian]. 
UDC 021.6(477)

\author{
Alona Motko, \\ PhD Student, \\ Information Technology Department, \\ Kyiv National University of Culture and Arts \\ (Kyiv, Ukraine) \\ e-mail: alyona94@meta.ua \\ ORCID: 0000-0002-5513-82X
}

\title{
FUNCTIONAL POTENTIAL OF THE ACTIVITY OF THE NGO UKRAINIAN LIBRARY ASSOCIATION FOR THE DEVELOPMENT OF LIBRARY STUDIES
}

The article is devoted to disclosing the functional potential of the Ukrainian Library Association (UBA) as an open professional organization that focuses its efforts on developing librarianship in Ukraine and strengthening the democratic foundations of social development in the country.

The use of a set of research methods, the main of which were socio-communicative, systemic and functional methods, as well as empirical methods of inclusive and external observation, led to consideration of ULA and its activities from the standpoint of fulfilling its obligations, its compliance with library community expectations. Implementing certain functions of the ULA and its activities is revealed as a system of interconnected forms and tools that complement each other, enhancing the final effect.

The creation of the ULA is considered as a response of the professional community to the need to solve certain tasks and implement a number of functions in relation to the development of the national library business and society as a whole. For the first time, the functioning of UBA as an open adaptive leadership organization that implements organizational, mobilizationmotivating, communication-coordination, information, educational, scientific-methodical, consolidating, representative, advocacy, compensatory functions is substantiated. The content of these functions is revealed.

The purpose of the compensatory function is to provide libraries with the necessary theoretical and practical basis for the effective implementation of promising areas of activity in the absence of relevant approved guidelines at the national level. It was found that from the beginning of the ULA the statutory documents of the organization did not provide for the implementation of the compensatory function. Still, during the development of the association and expressing its focus on prompt and effective solutions to current problems in library development, its implementation became an important vector of the ULA.

Keywords: NGO The Ukrainian Library Association, ULA, ULA functions, library, library business, compensatory function. 